\title{
Current Needs of Business Owners and Managers, Business Schools' View
}

\author{
V.V. Mantulenko ${ }^{1, *}$ and D.V. Aleshkova ${ }^{1}$ \\ ${ }^{1}$ Samara State University of Economics, Samara, Russia
}

\begin{abstract}
This article investigates actual training programs of leading Russian business schools for entrepreneurs, managers, and business owners. The aim of this research is to analyze current trends in the Russian business education and compare them with experts' forecast and opinions about the orientation of Russian entrepreneurship to general management issues (complex, integrated consideration of business processes, cultural and value based approaches to business management). The main research methods are analysis, systematization, and generalization. Based on the results of this research work, the authors make a conclusion about the presence of a new development stage of Russian entrepreneurship characterized by new tasks and requirements, urgent needs and skills in demand.
\end{abstract}

Keywords: business schools, business education, entrepreneurial culture, Russian entrepreneurship.

\section{Introduction}

The transition from the industrial mitre to the cognitive world that we are now witnessing and actively participating in is more like a quantum leap from one reality to another, built on different principles, new values, and a reinterpretation of traditional truths. The experience accumulated by mankind is becoming obsolete faster and faster. Business experience is certainly historically significant, but it is less and less used as a basis for modern directors when making important strategic decisions. An information-based economy requires business owners and managers to master the tools for obtaining, processing, broadcasting and preserving information resources, to synthesize new knowledge, to create unique products and services, and to make decisions in conditions of high uncertainty and instability of the environment. At the same time, according to the observations of scientists, experts, and practitioners, today many Russian entrepreneurs and senior managers have an intellectual hunger, due to the fact that they know "their" business very well and manage it quite competently [19, 22]. Quite young Russian businesses as a class today have less and less pragmatic needs related to a global rethinking of the process of creating business models, intellectual communication on topics that are not directly related to their professional sphere.

\footnotetext{
* Corresponding author: mantoulenko@mail.ru
} 
Increasingly, scientific discussions use the term "intellectual entrepreneurship" as a new conceptual framework that requires its own unique methodology. The source of the main transformations of modern business education is the thesis that a person should be able to build their intellectual world, including in the business space. Entrepreneurship as a human activity is increasingly associated with creativity. Educational systems of various levels are aimed at forming an entrepreneurial and creative attitude to one's own life [24]. Life itself is considered as a creative project, and entrepreneurship is not just a way to make money ("profit-making machine"), but is defined as the search for opportunities that are beyond the resources that are available today, as an opportunities for development.

Today we can clearly see the drift of Russian entrepreneurship towards society, more and more often business is not about money, but about pleasure, and more and more clearly entrepreneurs realize that they sell not just goods, services and works, but "emotions". The term "earn" is increasingly found not only in combination with the word "money", but also "trust and loyalty of customers", "respect", "reputation". There is a new format of competition - competition for the most accurate satisfaction of the needs of society, designing, foreseeing the needs of the future right now. In these conditions, analytics skills are extremely in demand. It is proved that digital technologies solve analytical problems faster and better than a human. However, an economy based on knowledge and information is not only an economy of algorithms and diagrams, graphs and indicators, it is also an economy of intuition and emotions, impressions and unconventional thinking. In this context, human intelligence today and in the near future is unlikely to be able to give up its leading position to artificial intelligence.

The purpose of this work is to consider the current needs of Russian entrepreneurship, the required competencies in the context of the global transformation of labor markets and the economy as a whole. In accordance with this goal, the main research tasks were to analyze the current requirements of the labor market, trends, development trends of entrepreneurial competencies, as well as the suggestions of the largest business schools in the Russian Federation in this context.

\section{Literature review}

Modern researchers and experts point out a number of skills as key to the development of entrepreneurial competencies in the near future. These include creativity [20], readiness for change $[14,15]$, the ability to solve complex problems, and critical thinking in the context of general competencies and skills that are already in demand in the global labor market. Entrepreneurs, business consultants, coaches and business coaches themselves are often talking about the transition from "business models" to network interaction and cooperation, creating business ecosystems (value networks and business ecosystems) $[7,12$, 13].

On the one hand, the sphere of educational services today (especially business education) strives to adapt to the requirements of customers and their needs in order to bring theory as close as possible to practice. On the other hand, the problems of the gap between the competencies and knowledge generated by different business schools and the real requirements of the rapidly changing labor market and business context are not new, but they are still relevant $[1,8]$. Peter Trkman points out the need for a deeper study of the content value of existing business schools [16]. Ahuja \& Purankar consider factors which impact the quality of business school education and help understand employer expectations from different sectors [21].

The effectiveness of business schools' operation is considered in various studies. First of all, the focus is on the composition of experts who are engaged in the training process. In 
most cases, it is the quality of teaching that helps to master a particular curriculum more successfully. It is necessary to take into account the specifics of the target audience in order to adapt business programs to them [11]. Practical experience shows that the most successful method for the main target groups is discussing and solving various business cases. It is used in business schools of different countries [4] and important for real entrepreneurs and those who are only entering the business and want to implement the gained knowledge as fully and efficiently as possible, form competencies and skills which are relevant in the modern VUCA world. The issue of competencies that are especially significant for the contemporary business world is also highly debatable. The new economic paradigm provides modernization of educational business programs in the direction of their local sensitivity, interpersonal relations, and socialization of the individual [18]. Such trends shape needs of target groups and require the educational processes modernization that is why the analysis of existing business schools is so important for potential consumers at the present time.

\section{Methodology}

The main research methods were the analysis, synthesis and generalization of scientific literature on the studied issues, official information from business school websites, interviews with experts in the field of labor economics, management and economic sociology. New Professions Atlas, developed by the Agency for Strategic Initiatives and the SKOLKOVO International School of Management in 2014, publications of the World Economic Forum in 2019, PwC in Russia in 2018 were analyzed [17]. Within the framework of the research work, the author relied on the principles of theoretical and practical significance of the research results, its relevance and novelty, consistency. Information brochures, descriptions of training courses and programs of leading business schools in Russia, whose target audience is entrepreneurs and managers, were the actual material.

The research sample consists of 6 leading Russian business schools, according to the National Ranking, and it was composed based on the following criteria:

- the sum of scores by independent experts and students,

- estimation of learning parameters (arithmetic mean): income growth, career growth, usefulness of business communications, personal and professional development,

- $\quad$ cost of training [23].

\section{Results}

Based on the analysis of educational programs and courses of leading business schools in Russia, we identified the most popular entrepreneurial competencies and the intersection points of the real offer to entrepreneurs and senior and middle executives with the forecasts of expert analysts regarding changes in this area (Table 1).

Table 1. Educational programs for entrepreneurs

\begin{tabular}{|c|c|l|}
\hline $\begin{array}{c}\text { Name of the } \\
\text { program } \\
\text { (Business school) }\end{array}$ & Target group & \multicolumn{1}{c|}{ Key points of the program } \\
\hline $\begin{array}{c}\text { Startup Academy } \\
\text { (SKOLKOVO) }\end{array}$ & $\begin{array}{c}\text { Young entrepreneurs, } \\
\text { founders of startups } \\
\text { with an innovative } \\
\text { business model }\end{array}$ & $\begin{array}{l}\text { - combinations of techniques that work through } \\
\text { thinking; } \\
\text { - formation of the entrepreneur's networking for } \\
\text { building investment-attractive projects; } \\
\text { - creating and testing business models; }\end{array}$ \\
\hline
\end{tabular}




\begin{tabular}{|c|c|c|}
\hline & & - interaction with (potential) investors. \\
\hline $\begin{array}{l}\text { SKOLKOVO } \\
\text { Workshop } \\
\text { (SKOLKOVO) }\end{array}$ & $\begin{array}{c}\text { Entrepreneurs, } \\
\text { managing owners, } \\
\text { general and functional } \\
\text { directors of companies } \\
\text { that already own a } \\
\text { business and have more } \\
\text { than } 10 \text { years of } \\
\text { management experience. }\end{array}$ & $\begin{array}{l}\text { - «rebuilding of the business model and analysis } \\
\text { of new markets»; } \\
\text { - creating your own business model; } \\
\text { - development of business strategy and personal } \\
\text { development trajectory; } \\
\text { - changing the scale of business and expanding } \\
\text { planning horizons. }\end{array}$ \\
\hline $\begin{array}{l}\text { Practicum Global } \\
\text { Shift } \\
\text { (SKOLKOVO) }\end{array}$ & $\begin{array}{l}\text { Managing owners, top } \\
\text { managers, and } \\
\text { functional directors. }\end{array}$ & $\begin{array}{l}\text { - design and test a global strategy; } \\
\text { - "entrepreneur ontology" - basic concepts and } \\
\text { schemes that define the global nature of business } \\
\text { activity; } \\
\text { - project work on creating a global company; } \\
\text { - business modeling is a rebuilding of the } \\
\text { business model for global markets. }\end{array}$ \\
\hline $\begin{array}{l}\text { Global Shift } \\
\text { Expedition } \\
\text { (SKOLKOVO) }\end{array}$ & $\begin{array}{l}\text { Managing owners, top } \\
\text { managers, and } \\
\text { functional directors. }\end{array}$ & $\begin{array}{l}\text { - opportunity to explore new territories, markets, } \\
\text { consumer culture and entrepreneurial } \\
\text { ecosystems; } \\
\text { - to see new business models and partnerships, } \\
\text { to get socio-cultural experience and to exchange } \\
\text { insights behind the history of the country; } \\
\text { partnerships, to get socio-cultural experience } \\
\text { and exchange insights; } \\
\text { - scenario planning and research-based learning. }\end{array}$ \\
\hline $\begin{array}{l}\text { SKOLKOVO } \\
\text { Workshop center } \\
\text { (SKOLKOVO) }\end{array}$ & $\begin{array}{l}\text { Entrepreneurs and their } \\
\text { teams that build a } \\
\text { strategy in situations of } \\
\text { market change and } \\
\text { business transformation. }\end{array}$ & $\begin{array}{l}\text { - development of strategic development projects } \\
\text { and their preparation for implementation; } \\
\text { - formation of a common strategic vision of the } \\
\text { business and organization of strategic } \\
\text { communication between the company's key } \\
\text { leaders } \\
\text { - representation system for business scaling and } \\
\text { deployment of new business directions; } \\
\text { - business transformation practices for reaching } \\
\text { the next scale; } \\
\text { - development of competencies necessary for } \\
\text { managing the transformation process aimed at } \\
\text { changing the scale of the business. }\end{array}$ \\
\hline $\begin{array}{l}\text { "Entrepreneurship } \\
\text { and company } \\
\text { management" } \\
\text { (Ranepa) }\end{array}$ & $\begin{array}{l}\text { Business owners who } \\
\text { participate in } \\
\text { management or perform } \\
\text { control functions, } \\
\text { directors with an } \\
\text { entrepreneurial mindset. }\end{array}$ & $\begin{array}{l}\text { - formation of skills and abilities to carry out } \\
\text { business activities and manage the company at } \\
\text { different stages of its life cycle; } \\
\text { - system representation of business, practical } \\
\text { tools in the field of organization management. }\end{array}$ \\
\hline $\begin{array}{l}\text { "Managerial } \\
\text { competence of a } \\
\text { director" (Business } \\
\text { school IMISP) }\end{array}$ & $\begin{array}{l}\text { Directors who already } \\
\text { have initial experience } \\
\text { in creating and } \\
\text { developing a business, } \\
\text { as well as those who } \\
\text { plan to become a } \\
\text { successful director. }\end{array}$ & $\begin{array}{l}\text { - improving personal efficiency, management } \\
\text { efficiency and business interaction; } \\
\text { - development of key management } \\
\text { competencies; } \\
\text { to move to a new quality level. }\end{array}$ \\
\hline $\begin{array}{l}\text { "Unconscious } \\
\text { scenarios in business: } \\
\text { how much does your } \\
\text { choice cost?" } \\
\text { (Business school } \\
\text { IMISP) }\end{array}$ & $\begin{array}{l}\text { The target group is not } \\
\text { specified. }\end{array}$ & $\begin{array}{l}\text { - the discovery of their own unconscious } \\
\text { scenarios in business; } \\
\text { - development of a conscious implementation } \\
\text { scenario and obtaining quality changes; } \\
\text { - developing a conscious scenario as a basis for } \\
\text { implementing and obtaining quality changes; }\end{array}$ \\
\hline
\end{tabular}




\begin{tabular}{|c|c|c|}
\hline & & $\begin{array}{l}\text { - mastering effective communication tools - } \\
\text { filters, metaprograms, emotional intelligence. }\end{array}$ \\
\hline $\begin{array}{l}\text { NASA program: } \\
\text { influencing people } \\
\text { through a model of } \\
\text { the communication } \\
\text { process } \\
\text { (Process } \\
\text { Communication } \\
\text { Model(C) (Business } \\
\text { school IMISP) }\end{array}$ & $\begin{array}{c}\text { Directors and leaders of } \\
\text { business teams, business } \\
\text { owners. }\end{array}$ & $\begin{array}{l}\text { - constructive communication and business } \\
\text { efficiency improvement; } \\
\text { - choosing the optimal strategy for interaction in } \\
\text { negotiations, management, partnership, etc.; } \\
\text { - formation of effective business teams; } \\
\text { - motivating and managing your own } \\
\text { motivation; } \\
\text { - prevention of manipulation. }\end{array}$ \\
\hline $\begin{array}{l}\text { Business Storytelling } \\
\text { (Business school } \\
\text { IMISP) }\end{array}$ & $\begin{array}{l}\text { Entrepreneurs-owners of } \\
\text { companies, middle and } \\
\text { senior managers, } \\
\text { directors of functions } \\
\text { and directions. } \\
\end{array}$ & $\begin{array}{l}\text { - attracting the audience's attention; } \\
\text { - retention of attention during a public speech; } \\
\text { - meaningful performance; } \\
\text { - designing an advertising/PR campaign. }\end{array}$ \\
\hline $\begin{array}{l}\text { "Project management } \\
\text { in the field of social } \\
\text { entrepreneurship» } \\
\text { (High School of } \\
\text { Management of St. } \\
\text { Petersburg State } \\
\text { University, St. } \\
\text { Petersburg) }\end{array}$ & $\begin{array}{l}\text { Current and potential } \\
\text { social entrepreneurs, as } \\
\text { well as managers of } \\
\text { companies that develop } \\
\text { projects in the field of } \\
\text { social entrepreneurship. }\end{array}$ & $\begin{array}{l}\text { - studying of the comparative experience of } \\
\text { social entrepreneurship in Russia and in the } \\
\text { world; } \\
\text { - comprehensive study of the most important } \\
\text { aspects of project management in the field of } \\
\text { social entrepreneurship; } \\
\text { - development of professional management } \\
\text { competencies necessary for the successful } \\
\text { implementation of projects in the field of social } \\
\text { entrepreneurship. }\end{array}$ \\
\hline $\begin{array}{l}\text { MBA "Challenges of } \\
\text { the digital world" } \\
\text { (High School of } \\
\text { Management of St. } \\
\text { Petersburg State } \\
\text { University, St. } \\
\text { Petersburg) }\end{array}$ & $\begin{array}{l}\text { Business owners and } \\
\text { directors who want to } \\
\text { take the company to the } \\
\text { next level using } \\
\text { innovative and } \\
\text { technological methods. }\end{array}$ & $\begin{array}{l}\text { - strategic management, digital leadership, } \\
\text { change management; } \\
\text { - value-based management;; } \\
\text { - effective communication; } \\
\text { - flexible team management. }\end{array}$ \\
\hline
\end{tabular}




\begin{tabular}{|c|c|c|}
\hline $\begin{array}{l}\text { «Effective Director» } \\
\text { (Moscow } \\
\text { International Higher } \\
\text { School of Business } \\
\text { MIRBIS) }\end{array}$ & $\begin{array}{c}\text { Middle and senior } \\
\text { managers, entrepreneurs } \\
\text { interested in increasing } \\
\text { their own capitalization, } \\
\text { as well as developing } \\
\text { managerial } \\
\text { competencies and } \\
\text { finding new solutions } \\
\text { for business. }\end{array}$ & $\begin{array}{l}\text { - comprehensive view on the company's work; } \\
\text { - the ability to systematize knowledge, create } \\
\text { and then put into practice your own business } \\
\text { project, taking into account the knowledge and } \\
\text { competencies obtained in the program (an } \\
\text { interdisciplinary group project). }\end{array}$ \\
\hline $\begin{array}{c}\text { Personal and } \\
\text { professional } \\
\text { management skills - } \\
\text { soft skills (Higher } \\
\text { school of business of } \\
\text { the State University } \\
\text { of Management) }\end{array}$ & Directors and managers. & $\begin{array}{l}\text { - issues of improving personal and professional } \\
\text { effectiveness of directors; } \\
\text { - leadership and management communications; } \\
\text { - change control; } \\
\text { - stress management and emotional intelligence; } \\
\text { - effective presentations and public speaking. }\end{array}$ \\
\hline $\begin{array}{l}\text { «General } \\
\text { Management» } \\
\text { (Higher school of } \\
\text { business of the State } \\
\text { University of } \\
\text { Management) }\end{array}$ & $\begin{array}{c}\text { Owners of small and } \\
\text { medium-sized } \\
\text { businesses, middle } \\
\text { managers. }\end{array}$ & $\begin{array}{l}\text { - a systematic view on the business processes of } \\
\text { companies, enterprises and organizations; } \\
\text { - optimization of strategic planning skills and all } \\
\text { management activities; } \\
\text { - fundamentals of strategic thinking;; } \\
\text { - ability to analyze processes, identifying factors } \\
\text { that determine their effectiveness and } \\
\text { productivity; } \\
\text { - an idea of how to successfully adapt to } \\
\text { changing conditions in the business } \\
\text { environment. }\end{array}$ \\
\hline
\end{tabular}

Source: Own processing based on $[2,3,5,6,9,10]$.

Analyzing the data in the table, there are several key areas in which work is conducted in all these business schools, it is possible to allocate 4 basic directions: the creation and transformation of business models; globalization and expansion of business; development of business development strategies; personal and managerial development. The directions were formulated based on the key points of the programs identified by the business schools themselves. To a greater extent, only 3 business programs deal with issues of globalization and business expansion. A quarter of the listed business schools are focused on training in the development of their own business models, and 6 training programs out of 15 are focused on training in strategic development and strategic planning within their own business structures. Issues of personal and managerial development of entrepreneurs have the maximum coverage. These programs are implemented in all the analyzed business schools. Based on this, we can clearly identify relevant areas for our own development, which are of great importance for modern entrepreneurs.

For young Russian entrepreneurship, an interest in business modeling, strategic planning and management, building effective teams, and generally raising awareness in business, focusing on the value aspects of business is an extremely important stage of development that are relevant for today. It is also important that the offer of business schools to Russian entrepreneurs and managers includes aspects that are important today on a global scale: networking, development of soft skills (critical, systems thinking, strategic thinking, emotional intelligence), creation of business ecosystems, and change management. However, the wording in the course descriptions is not always clear and specific. For example, a combination of techniques that work through thinking (which?); development of key management competencies (which?). The SKOLKOVO Practicum program describes itself as "the only program for working with entrepreneurial thinking", in fact, it is not true compared to other business schools. Programs that include the study of 
the comparative experience of entrepreneurship in Russia and in the world, addressing issues of personal and professional effectiveness are interesting.

Speaking about the target groups that the activity of the considered business schools is aimed at, we can also distinguish 4 general groups, which include managing owners, functional executive, project managers and young entrepreneurs. At the same time, some business schools identify managing owners and functional managers as the target group. Project managers and young entrepreneurs are identified as their target groups for only 2 and 4 business programs. All this indicates that business schools are more focused on active entrepreneurs than on those who are just starting their way in business. This is primarily due to the desire of entrepreneurs to develop their own business, maintain its importance and relevance in a changing world, follow global trends and at the same time do not stop in personal development. Such programs combine the needs of mature entrepreneurs to the fullest extent.

\section{Discussion}

Program suggestions of various schools are developed based on the needs of the target audience. Business schools are more focused on experienced entrepreneurs and practicing managers. This trend may be due to the fact that the thinking of experienced entrepreneurs does not have a sufficient level of flexibility and requires additional incentives from educational institutions. Some business schools still identify young, aspiring entrepreneurs who have just started their business career or are at the stage of the idea and development of a business plan, as their target group. Considering the difference between these target groups, it makes sense to study their features, which may affect the content of programs presented by business schools (Table 2).

Table 2. Features of the needs of experienced and novice entrepreneurs

\begin{tabular}{|c|c|}
\hline Experienced entrepreneurs & Novice entrepreneurs \\
\hline $\begin{array}{l}\text { - The presence of a business that has } \\
\text { already existed for a long time and is } \\
\text { currently operating; } \\
\text { - Conservative views on business } \\
\text { management are possible; } \\
\text { - An established, not always flexible } \\
\text { mindset is possible; } \\
\text { Outdated knowledge in the field of } \\
\text { entrepreneurship or only accumulated } \\
\text { own entrepreneurial experience is } \\
\text { possible. }\end{array}$ & $\begin{array}{l}\text { - Having an idea of your own business or } \\
\text { a young business that is already } \\
\text { opened; } \\
\text { - Availability of fresh knowledge, } \\
\text { usually field-specific education. } \\
\text { - Flexible thinking, quick adaptation to } \\
\text { changing environmental conditions; } \\
\text { - Lack of experience in business } \\
\text { management and planning. }\end{array}$ \\
\hline $\begin{array}{l}\text { - Desire to develop and expand your o } \\
\text { - Creating and(or) developing / transfo } \\
\text { - Personal development and self-impro }\end{array}$ & vement. \\
\hline
\end{tabular}

Source: Own processing.

As can be seen from Table 2, the two target groups under consideration have both differences and common features. It can be assumed that business schools often choose existing entrepreneurs due to the fact that experienced entrepreneurs are already more morally stable and know the specifics of the market functioning. All this suggests that they will be easier to work with. However, experience shows that a lack of flexibility of thinking 
can significantly complicate the task. For successful development there is not always enough experience, it is important to respond to new trends and constantly evolve. This explains the need to retrain this target group. Experienced entrepreneurs realize that the reorientation of society forces entrepreneurs to rebuild their own business in accordance with the needs of society.

Younger entrepreneurs have sufficient flexibility of thinking, they are ambitious and easily generate ideas for their own business. Most novice entrepreneurs have specialized education, which greatly facilitates their further training. However, their lack of experience does not allow them to fully assess the risks and features of the market functioning. It can be concluded that the general desires for experienced and young entrepreneurs to be engaged in self-development and development of their own business is largely dictated by society, but business schools believe that training is more necessary for experienced entrepreneurs, since they are the ones who need a radical restructuring of thinking. It is important to direct young entrepreneurs in the right direction and help them to build their own business model. This shows the specifics of training specific target groups and the choice of programs for them.

\section{Conclusion}

The current situation in society interprets new directions for business development, which makes it necessary to reorient business in accordance with existing socio-cultural trends and tendencies. More and more attention is being paid to areas aimed at developing soft-skills, emotional intelligence, and other innovative solutions that are being actively implemented in modern business. There is a reorientation of entrepreneurship towards the formation of cognitive skills designed to revolutionize the field of modern business management. This is primarily due to the reluctance of entrepreneurs to stop at what they have achieved and the need to find new, sometimes not obvious solutions to open up horizons. Constant modernization, moving away from the strictly material to the mental, allows the entrepreneur to quickly adapt their business to changing environmental conditions. At the same time, it gets the opportunity not only to preserve the material and intellectual resources embedded in the business, but also to significantly increase them. These areas are the basis of the programs offered by business schools to modern and intellectually curious entrepreneurs.

Considering the proposals of the most popular business schools, 4 main directions of their activities were identified, the most popular of which were programs related to the personal and managerial development of entrepreneurs. At the same time, the activities of business schools are aimed more at existing entrepreneurs and functional managers. Experts' forecasts regarding the orientation of young Russian entrepreneurship towards a comprehensive view of business that takes into account the socio-cultural features of society's development are confirmed by the range of current programs offered to entrepreneurs by existing business schools.

\section{References}

1. A. Blue: 5 things we know about the jobs of the future. World Economic Forum 2020. URL: https://www.weforum.org/agenda/2020/01/future-jobs-and-skills-in-demand/. Accessed: 29.04.2020. (2020).

2. Agency for Strategic Initiatives. Atlas of new professions. 2014. URL: https://asi.ru/reports/16344/. Accessed: 29.04.2020. 
3. Business School IMISP: Programs. (2020). URL: https://www.imisp.ru/programmes/. Accessed: 26.08.2020.

4. F. Mu, J. Hatch: Accelerating the introduction of the case method into Chinese business schools: An action research approach. Educational Action Research, 28(4), 609-625. DOI:10.1080/09650792.2019.1642774. (2020).

5. F.R. David, M.E. David, F.R. David: What are business schools doing for business today? Business Horizons, 54(1), 51-62. DOI: 10.1016/j.bushor.2010.09.001. (2011).

6. High School of Management of St. Petersburg State University: Programs. (2020). URL:

https://gsom.spbu.ru/programmes/exed/open_programs/dop_upravlenie_proektami_v_ oblasti_socialnogo_predprinimatelstva/. Accessed: 26.08.2020.

7. Higher School of Business of the State University of Management (GUU): Programs. (2020). URL: https://hbs-guu.ru/program/increase-qualitication/personal-andprofessional-management-skills-soft-skills/. Accessed: 26.08.2020.

8. Institute of Business and Business Administration of the Russian Academy of National Economy and Public Administration (Ranepa): Retraining and skills development. (2020). URL: https://ibda.ranepa.ru/programs/povyshenie-kvalifikatsiiprofperepodgotovka/povyshenie-kvalifikatsii/moduly-mba/. Accessed: 26.08.2020.

9. L. Broccardo, A. Zicari: Sustainability as a driver for value creation: A business model analysis of small and medium enterprises in the Italian wine sector. Journal of Cleaner Production, 259, 120852. DOI: 10.1016/j.jclepro.2020.120852. (2020).

10. M. Farashahi, M. Tajeddin: Effectiveness of teaching methods in business education: A comparison study on the learning outcomes of lectures, case studies and simulations. International Journal of Management in Education, 16(1), 131-142. (2018).

11. M. Rhaiem, N. Amara: Determinants of research efficiency in Canadian business schools: Evidence from scholar-level data. Scientometrics, 125(1), 53-99. DOI:10.1007/s11192-020-03633-z. (2020).

12. Moscow International Higher School of Business MIRBIS: Programs. (2020). URL: https://mirbis.ru/mba/effective-director/. Accessed: 26.08.2020.

13. Moscow Management School Skolkovo: Educational programs. (2020). URL https://common.skolkovo.ru/ru/educational-programmes/. Accessed: 26.08.2020.

14. P. Gregori, P. Holzmann: Digital sustainable entrepreneurship: A business model perspective on embedding digital technologies for social and environmental value creation. Journal of Cleaner Production, 272, 122817. (2020). DOI: 10.1016/j.jclepro.2020.122817.

15. P. Leviäkangas, R. Öörni: From business models to value networks and business ecosystems - What does it mean for the economics and governance of the transport system? Utilities Policy, 64, 101046. DOI: 10.1016/j.jup.2020.101046. (2020).

16. P. Trkman: Value proposition of business schools: More than meets the eye. The International Journal of Management Education, 17(3), 100310. DOI: 10.1016/j.ijme.2019.100310. (2019).

17. PwC in Russia: Workforce of the future. The competing forces shaping 2030. (2018). URL: $\quad$ https://www.pwc.ru/ru/publications/the-future-of-the-labour-market.html. Accessed: 29.04.2020.

18. S. Waddock: Will businesses and business schools meet the grand challenges of the era? Sustainability (Switzerland), 12(15), 60-83. DOI:10.3390/su12156083. (2020).

19. S.I. Ashmarina, V.V. Mantulenko, E.P. Troshina: Readiness to changes as one entrepreneurial value of the innovation-oriented economy. In S. Ashmarina S., M. Vochozka (Eds.), Sustainable Growth and Development of Economic Systems. Contributions to Economics (pp. 157-166). (Springer, Cham, 2019). DOI: 10.1007/978-3-030-11754-2_12. 
20. S.L. de Vasconcellos, I.L. Garrido, R.C. Parente: Organizational creativity as a crucial resource for building international business competence. International Business Review, 28(3), 438-449. DOI: 10.1016/j.ibusrev.2018.11.003. (2019).

21. V. Ahuja, Sh. Purankar: Quality business school education and the expectations of the corporate - A research agenda. Procedia Computer Science, 139, 561-569. DOI: 10.1016/j.procs.2018.10.209. (2018).

22. V.V. Mantulenko, D.V. Aleshkova: Comparison of leading business schools in Russia and in the world. In V.V. Mantulenko (Ed.), Proceedings of PEDTR 2019 18th International Scientific Conference "Problems of Enterprise Development: Theory and Practice”. European Proceedings of Social and Behavioural Sciences, 82 (pp. 1-6). (European Proceedings, London, 2020). DOI: 10.15405/epsbs.2020.04.1.

23. The rating of Russian business schools MBA.SU (2020). URL: https://www.mba.su/narodnyj_rating_bschools_2019/. Accessed: 23.10.2020.

24. Your Training: Soft skills. (2019). URL: https://utraining.ru/2019/11/13/soft-skills-2/. Accessed: 29.04.2020. 